\title{
Comparative Area Studies and the Study of the Global South
}

\author{
R. Sil \\ University of Pennsylvania, Philadelphia, USA
}

\author{
A.I. Ahram \\ Virginia Tech, Arlington, USA
}

\begin{abstract}
Comparative Area Studies (CAS) offers a template to bring the Global South back into the foreground of social science inquiry. CAS urges researchers to grapple directly with empirical variations derived from across the seemingly different global regions. CAS offers three comparative modes: intra-regional, cross-regional, and transregional. A number of scholars have used CAS's comparative rubrics, even without knowing about the wider CAS agenda and program. CAS unsettles assumptions about discrete, fixed "regional" or civilizational blocks as well as about nomothetic theory-building aimed at universal or general laws. At the same time, CAS engages in the idea of mediumrange theory-building, focusing empirical rigor and induction in order to create concepts and analyses that are portable yet contextualized. These macro-historical theories must be attentive to spatial and temporal variation in the social world. Claims of universalism are suspect. For the study of the Global South, in particular, CAS provides a path for aggregating and leveraging the wide range of observations and interpretations area specialists have to offer on regions as diverse as South Asia, the Middle East, Latin America, and sub-Saharan Africa. CAS thus changes the division of labor within social science to allow greater input for scholarship derived from and originating in the developing world.
\end{abstract}

Key words: Area studies, qualitative methods, multimethod research, democratization, institutions

For citation: Sil, R. \& Ahram, A.I. (2020). Comparative Area Studies and the Study of the Global South. Vestnik RUDN. International Relations, 20 (2), 279-287. DOI: 10.22363/2313-0660-2020-20-2-279-287

Научная статья

\section{Сравнительное регионоведение и исследование Глобального Юга}

\author{
Р. Сил \\ Университет Пенсильвании, Филадельфия, США
}

А.И. Ахрам

Политехнический университет Виргинии и университет штата, Арлингтон, США

\begin{abstract}
Сравнительные региональные исследования (СРИ) предлагают инструментарий, позволяющий вернуть Глобальный Юг на передний план исследований в области социальных наук. СРИ призывают исследователей не бояться сталкиваться и изучать, казалось бы, значительную эмпирическую вариацию, обнаруживаемую при сравнении различных регионов мира. СРИ предлагают три сравнительных метода: внутрирегиональный, сравнение соседних регионов и трансрегиональные сравнения. Ряд исследователей уже применяли методику СРИ до того, как они были выделены в отдельное методологическое направление со своими более глобальными задачами и представлениями о сравнительных исследованиях в целом. СРИ разрушают предположения о дискретных, фиксированных «региональных» или цивилизационных блоках, а также построении номотетических теорий, нацеленных на универсальные законы. В то же время СРИ продвигают идею построения теории среднего уровня, концентри-
\end{abstract}

(C) Sil R., Ahram A.I., 2020

This work is licensed under a Creative Commons Attribution 4.0 International License.

https://creativecommons.org/licenses/by/4.0/ 
руясь на большей эмпирической строгости и индукции, с целью создания терминологии и анализа, являвшихся бы экстраполируемыми, но в то же время контекстуализируемыми. Эти макроисторические теории должны более тщательно учитывать пространственные и временные изменения в социальном мире. В частности, для изучения Глобального Юга СРИ дают возможность агрегации и использования широкого спектра наблюдений и интерпретаций, предлагаемых специалистами по столь различным регионам, как Южная Азия, Ближний Восток, Латинская Америка и Тропическая Африка. Таким образом, СРИ вносят изменения в разделение труда в социальных науках, позволяющие предоставить бо́льшую роль исследованиям, проводимым в развивающихся странах.

Ключевые слова: регионоведение, качественные методы, мультиметодные исследования, демократизация, институты

Для цитирования: Sil R., Ahram A.I. Comparative Area Studies and the Study of the Global South // Becтник Российского университета дружбы народов. Серия: Международные отношения. 2020. Т. 20. № 2. С. 279287. DOI: $10.22363 / 2313-0660-2020-20-2-279-287$

\section{Introduction}

Social scientists have always struggled to find a balance between the drive to develop universal theories and the imperative of engaging with immense varieties of empirical observations gleaned from the social world. The social sciences, including political science and sociology, remain Northern (or Western) centered. Key theories, such as those related to economic and political development, implicitly assume that North's experience are modally prevalent, inevitable, or normatively superior. Moreover, the predominance of quantitative studies, particularly survey responses, privileges modes of inquiry that were designed and customized to suit the study of advanced industrial polities like those seen in the Global North. All of this cumulatively pushes the study of the developing world, particularly the Global South, to a periphery. The different areas that constitute the Global South surely provide a mix of empirical exotica, but the impact of findings about these areas on mainstream social science theories has been relatively minor due to the tendency to treat (even if unintentionally) each of the individual areas as unworthy of significance for the purposes of theoretical investigation or methodological innovation.

Comparative Area Studies (CAS) offers a template to bring the Global South back into the foreground of social science inquiry. In offering methodological approaches for intra-regional, cross-regional, and inter-regional comparison, CAS compels researchers to grapple directly with empirical variations derived from across the seemingly different regions used to create and bound area expertise [Ahram, Köllner, Sil 2018]. CAS unsettles assumptions about discrete, fixed "regions" as well as about nomothetic theorybuilding aimed at universal laws. At the same time, it does not jettison the idea of theorybuilding writ large and instead insists on a more rigorous, empirical, and inductive path toward middle-range, macro-historical theory formation that is attentive to spatial and temporal variation in the social world. For the study of the Global South, in particular, CAS provides a path for aggregating and leveraging the wide range of observations and interpretations area specialists have to offer on regions as diverse as South Asia, the Middle, East, Latin America, and SubSaharan Africa.

\section{Re-positioning Area Studies, Advancing Cross-Area Studies}

The seemingly endless debates between nomothetic social science, intent on building broad, and area studies specialists, who focused more narrowly on a single country or region, have come to a merciful truce [Bates 1997]. Still, the challenge of balancing the standards and expectations of area studies communities with those of non-area specialists in political science remains.

There are a number of different strategies available for dealing with this tension. For some researchers, the old nomothetic dictum of replacing proper nouns remains a worthy, albeit difficult, objective. There is no questioning the predominance of quantitative research that eschews any mention of specificity of place or locus except when absolutely unavoidable [King 
1996]. Cross-national large- $\mathrm{N}$ comparison and survey research addressing individual attitudes try to minimize the significance of the particular as much as possible, using geographi-cally specific nominal variables (“dummy variables") to hold place as a constant [Harbers, Ingram 2017]. Formal and game theoretical models are even more abstract, seeking essentially to make area irrelevant. The result are analyses that fit within the bounds of and largely reproduce different versions of what Andrew Abbott dubs "General Linear Reality" (GLR).

GLR assumes a distinctly flattened social ontology in which the social world consists of fixed entities with variable attributes, causal patterns are singular and definitive, and units of analysis are independent and not interconnected in any meaningful way. Furthermore, causation tends to flow in a single direction, from large entities affecting small ones, but not the other way around [Abbott 1988]. The value of area studies, to those adopting the GLR perspective, derive largely from acquiring and providing "novel" data that can be grist for further theoretical interrogation and theory testing and refinement.

Despite the unmistakable ascent of this quantitative research beholden to GLR assumptions, however, a sizable and very active contingent within the social sciences retain an abiding interest in engaging area specialists in a particular area of the world. For them, space and contexts not only matter, but define the immense circumference of social changes [Goodin, Tilly 2006]. Area studies scholars often anchor their research in the epistemological traditions of the new institutionalism, which offers a sophisticated conceptual toolbox to explain both variation and general commonalities in social development and could be seen as an antidote to the inexorable pull of GLR [Peters 2019: 12; Ahram 2011].

Historical institutionalism, a sub-stream within new institutionalism, has developed notions such as "process-tracing", "critical junctures", "contingency" and "path dependence" for the design and presentation of qualitative research on a host of topics across the subfields of political science [Mahoney, Thelen 2015; Fioretos, Falleti, Sheingate 2016: 3-30].
Interpretivists research stands out as a somewhat smaller and perhaps more peripheral mode of engagement. These scholars tend to embrace ethnographic and participant observation styles of research. They are often more closely aligned with anthropology and what might be dubbed the humanist branch of area studies [Wedeen 2010; Schaffer 2018]. While those identifying with historical institutionalism are more likely to be considered "mainstream" within the discipline, both of these intellectual traditions have helped to preserve some space for area specialists doing stand-alone qualitative research within political science.

Some scholars have advocated multimethod research (MMR) as a possible way to bridge the divide and, in effect, capture the best of both worlds by combining qualitative area-focused scholarship in the form of case studies within mixed-methods projects, usually alongside formal models and/or regression analyses. Some MMR designs provide an avenue (or perhaps a convenient "cover") for scholars who remain deeply committed to studying particular areas and engaging area studies communities. For them, even if qualitative research is the primary objective, incorporating regression analyses or formal models can go a long way towards convincing non-area specialists to pay attention to the qualitative findings [Berg-Schlosser 2012].

One type of mixed-method research that has been gaining in popularity is the integration of qualitative research with field experiments. In this approach, research designs that most closely resemble laboratory experiments are seen as the most reliable path to improving causal inference. The best field experience demands deep area expertise to supply the contextual knowledge required for strong designs [Dunning 2012]. Dana El-Kurd's survey experiments on attitudes on security services, conducted amongst Palestinian university students, were extremely sensitive to the particulars of on-campus political alignments to elicit response. This effort certainly increased the internal validity of the research. However, it also circumscribed any 
claims that findings could be generalized to other Palestinians, much less to other societies [E1 Kurd 2019].

Too often, though, field experimenters are willing to elide important contextual constraints in their pursuit of generalizability and external legitimacy [McDermott 2011]. These efforts thus reinforce the tendencies of GLR, offering a social change in which variegation of space and time are ironed-out or elided. Consequently, at least some area studies specialists especially skeptical of MMR design as merely another kind of interloping. The proliferation of mixedmethods research since the 1990s has been extremely rapid and has had some unanticipated consequences, including shrinking the space available for single-method qualitative research [Ahmed, Sil 2012].

CAS is an intervention meant to bolster qualitative research by offering firmer methodological footing and justification. At the same time, it seeks to embolden quantitative researchers and urges them to consider broader temporal and spatial horizons [Köllner, Sil, Ahram 2018; Basedau, Köllner 2007; Soest, Stroh 2018]. CAS entails three different approaches to comparison:

- Intra-regional comparisons. These entail comparing entities within a geographic region or area, commensurate with traditional area studies approaches.

- Inter-regional comparison. These entail comparing different geographical regions or areas as whole analytical unites

- Cross-regional comparison. These entail comparing entities from different geographical regions or areas.

The instinct and inclination for such comparisons is not exactly new. Charles Tilly urged historical sociologists to embark on "huge comparisons" that traversed boundaries of scale and time in the 1980s [Tilly 1984]. More recently, Evelyne Huber implored political science to undertake systematic cross-regional comparative analysis [Huber 2003]. There are a number of notable studies that illustrate the value and relevance of cross regional qualitative comparisons, also suggesting that scholars may be practicing CAS without even knowing it. For example, Elisabeth Wood's study of the end of insurgencies and the negotiation of democratic pacts compared two countries located on two continents, El Salvador and South Africa [Wood 2000].

Wood's primary field of expertise is Central America, her language skills are limited to Spanish and Portuguese, and her research began with extensive fieldwork in El Salvador featuring interviews with not only government officials and party leaders but also field commanders of various insurgent guerrilla forces. However, she put off a detailed study of El Salvador that would later appear in a separate book [Wood 2003] and opted to delve into the case of South Africa. Wood did carry out fieldwork and interviews in South Africa, but she had training as an Africanist, did not speak any of the native languages beyond English, and limited her interviews to a significantly narrower range of actors (politicians, business groups, trade union officials). The point is not to raise doubts about Wood's treatment of South Africa, but rather to highlight the intellectual payoffs of her bold decision to delve into a second case in spite of not having extensive prior expertise on that case. That decision led to a paired comparison in which she was able to leverage a "least similar systems" research design that effectively made her argument more compelling to a wider audience. And she did this with sensitivity to the context that was only possible because she had previously amassed an impressive amount of country specific expertise that would not only be useful for one of the two cases but could also inform her judgment in designing her empirical investigation into the other case.

Similarly, Lieberman's more recent Boundaries of Contagion [Lieberman 2009] stands out for its leveraging of a cross-national study of Brazil and South Africa, alongside a sub-national (intra-regional) comparative analysis of Indian states, in addressing the question of why some governments have more effective and efficient responses to AIDS than others. In contrast to those who focus on the capacity and willingness of states to provide effective responses, Lieberman's general argument essentially focuses on the demand side, 
making a compelling case for how the institutionalization of ethnic divisions influence the extent to which the conditions and concerns of the most/least affected populations are actually revealed to governments. The most intriguing part of the evidence Lieberman offers on the basis of his cross-national and withincountry comparisons is the identification of two sets of mechanisms that link the initial conditions to the final outcome: the most affected groups fear the social stigma that may be attached to their groups should they publicly acknowledge their level of exposure to AIDS, whereas the least affected groups tend to feel themselves insulated from the problem. The deeper the institutionalization of these ethnic boundaries, the stronger the negative effect of both of these mechanisms on the likelihood of effective and efficient government responses.

In the wake of the turmoil caused by the Covid-19 pandemic, Lieberman's works represents an impressive exemplar of how to effectively triangulate information from different regions of the Global South to generate fresh theoretical insights that were previously missing in the literature. Had Lieberman only focused on one country or area, questions would have to be raised about the portability of the insights; but by combining cross-regional and intra-regional comparative analysis in a creative manner, Lieberman leaves us with an important work that is of relevance for the well-being of different groups throughout the regions of the Global South.

While the above examples are of studies by established comparativists who chose to go beyond relying solely on expertise in a single region, it is possible to find first books (often based on doctoral dissertations) that selfconsciously traverse regional silos [Saylor 2014; Sil 2002; Smith 2007]. Jason Brownlee's analysis authoritarianism is illustrative and exemplary in this respect [Brownlee 2007]. Brownlee cuts across Middle Eastern and Southeast Asian studies to develop a comparable set of cases featuring Egypt, Iran, Malaysia and the Philippines. The comparative study is designed to explain why electoral authoritarianism helps to preserve authoritarian rule in some cases (Egypt, Malaysia) while engendering more democratic contestation in others (Iran, the Philippines). Brownlee's Arabic language skills presumably aided his field research in Egypt, and his broader training as a Middle East area specialist likely gave him substantial background for Iran. But, by venturing into Malaysia and the Philippines despite the absence of a similar level of prior expertise in the Southeast Asian region, Brownlee is able to make a more compelling case for the portability of his argument. That the variation in outcomes cuts across the two regions of the Global South helps to strengthen Brownlee's theoretical claims about the importance of softliners who can press forward when a ruling party is unable to manage conflicts among elites. At the same time, the evidence is based on at least some fieldwork in both regions, with attention to country-specific scholarly debates as well as to the broader historical contexts shaping the emergence and structure of authoritarian regimes in each case. In all of the above examples, we find key insights about some dimension of political or economic change in the Global South that depended on being willing to stretch beyond one's initial area of expertise and to delve into a second or third region.

In practical terms, the CAS approach does not require that the researcher become expert on every country or area to be analyzed. And, it is certainly not reasonable to expect a researcher to keep learning new languages or finding new collaborators for each and every additional case in a small-N study [Skocpol, Somers 1980; Thies 2002]. It is usually possible and certainly worthwhile, however, for anyone trained as an area expert to study cases from a different area with an eye to regionally specific context conditions and with an awareness of how contending intellectual traditions and historiographic complexities shape discourses among the relevant area studies communities.

These studies highlight the payoffs of CAS in diving deeply into their cases and engage area studies debates while also identifying portable concepts and causal linkages through crossregional comparative analysis. In the process, CAS also serves an integrative function, 
expanding the channels of communication both between separate communities of area specialists interested in similar problems and between these communities and the discipline of political science writ large.

One of the most interesting additions to the repertoires of CAS comes from the emergence of qualitative comparative analysis (QCA). QCA builds of the logic of Boolean algebra and set theory to examine complex causal configurations across cases. Unlike the GLR modes predominant in large-n analysis, QCA is explicitly geared to address necessary and sufficient conditionality, which is a major feature in qualitative research [Rihoux, Ragin 2008; BergSchlosser 2012]. Recent steps have sought to link QCA with process tracing, another important tool in the qualitative arsenal. The initial "crisp" versions of QCA relied upon binary coding of a set of variables across a number of cases. In response to criticisms that this limited coding generates claims that are overly deterministic, fuzzy-set QCA has been designed to incorporate continuous variables that allow for a much wider range of potential configurations. The coding of cases and variables in QCA is thus paramount and demands intensive consideration from the research of both the underlying conceptual definition and the empirics of the case. Moreover, area-based knowledge provides crucial contextual information needed to identify the relevant variables across a given set of cases and to assign appropriate values to these variables for each case. Thus, while QCA is not as dependent as CAS on the skills or sensibilities of an area specialist, it does provide justification for continuing investment in area studies research, without which it not be possible to identify plausible case-specific causal configurations.

\section{CAS and the Question of Scale}

Like many modes of social science, CAS often defaults to the assumption that individual countries are the most appropriate or easiest unit to approach for analysis. This assumption, what Chernilo and Wimmer dub "methodological nationalism", is problematic on the theoretical level and self-limiting on the methodological one
[Chernilo 2011]. It presupposes that the locus of both cause and effect reside only at the nationallevel scale, unwittingly reproducing some of the key GLR assumptions.

CAS has a strong promise to push researchers to "scale up" or "scale down" qualitative research instead of defaulting to methodological nationalism. To scale up, scholars move away from focusing on individual countries to consider comparing entire regional blocks. As Peter Katzenstein and Amitav Acharya each argue, discrete and yet interconnected regional orders have become an especially important part of the global system [Katzenstein 2015; Acharya 2007]. Inter-regional comparison emphasizes the relevance of discrete region-wide attributes and processes that can play a crucial role in mediating causal forces thought to originate at the global or national levels. By de-centering the nation-state and focusing on regions, inter-regional comparisons are in a position to shed light on how regionlevel historical inheritances or transformational processes might mediate between global and local forces and influence the trajectories of discrete clusters of countries. Etel Solingen's study of the interplay between economic development, political economy, and nuclear proliferation in East Asia versus the Middle East shows how mechanisms of change differ by context [Solingen 2009]. Scott Mainwaring and Anibal Perez-Liñán's work on democratization similarly emphasizes unique regional distributions, anchoring the discussion in the question of Latin America's unique course toward democratization [Mainwaring, PérezLiñán 2007].

Regions, of course, are not innate or natural phenomena. They are often flexible depending on the specific research question. Moreover, they have varying degrees of porousness vis-à-vis the forces of globalization and internationalization. Yet, they still retain a regionally distinctive combination of economic, cultural, and institutional features that shape the behaviors and relations among countries within a given region [Sidaway 2013; Lewis, Wigen 1997].

Opposite scaling up is the possibility of scaling "down" to consider subnational units of 
analysis as objects for comparison [Snyder 2001]. This approach encompasses withincountry comparisons of cities or provinces as well as between-country comparisons of like units situated in different countries. The latter variant forfeits the possibility of controlling for national-level historical or societal or institutional attributes; but it gains more traction in analyzing how similarities and differences in those attributes might produce similar patterns of sub-national variation across different national settings. This fundamental design easily lends itself to cross-regional studies, where comparisons can focus on similar sets of sub-national units situated in different areas of the world. This is particularly useful for researching questions where the relevant sub-national dynamics are limited to countries that have certain common characteristics or face certain common challenges even though they are located in different areas of the world. This is the case, for example, with efforts to track variations in the efficacy of reforms designed to decentralize aspects of policymaking and expand the scope for grassroots civic engagement in Brazil, India and South Africa [Heller 2012].

Benjamin Smith and Thomas Pepinsky use contextually-sensitive comparisons of regions that suffered marginalization or exclusion from centrally-based state-building project. The result are sub-national peripheries in perpetual unrest, often times veering toward unrest, separatist and secessionist movements [Pepinsky 2017; Smith 2018]. Both inter-regional and sub-national comparative studies bolster the argument that area expertise is an extremely valuable asset for identifying the contextual knowledge needed to design and execute cross-regional comparative studies. Yet there are other, unheralded applications of the CAS mode in sub-national comparison. This includes the comparison of cities, such as Mark Frazier's comparative study of labor movements and mobilization in Shanghai and Mumbai [Frazier 2019]; the examination of cross-border trade flows and modes of production, as in Calvin Chen's examination of Chinese workers in the Italian textiles industry [Chen 2015; 2018]; and the study of stateless groups and diasporas, as Harris Mylonas and Nadav Shelef propose and implement [Mylonas, Shelef 2017].

\section{Conclusion}

CAS does not offer a grand or master theory of social change, either at the macro-level, in the way development or dependency theory does, or at the micro-level, as in the case of rational choice theory. It offers, though, a middle-range blueprint for modes of empirical inquiry to which many scholars, especially those with area training, are already inclined. This blueprint cannot by itself fortify the status of area specialists within political science. Thus, CAS also aims to induce area specialists to take an active role in framing the knowledge they generate in relation to evolving theoretical and methodological debates in the discipline. This implies a need to be more explicit and selfconscious in describing the epistemological assumptions and methodo-logical principles through which qualitative observations from one or more areas are interpreted in relation to general concepts and middle-range theories in the social sciences.

For the study of the Global South, in particular, CAS pushes a fount of empirical exotica from different locales to a place where theory generation and conceptual innovation can flourish. CAS allows us to draw upon crossregional, intra-regional and inter-regional comparative analysis to creatively aggregate the insights generated by, and initiate productive conversations between, various area studies communities concerned with different regions across the Global South. This by itself may not be enough to de-center knowledge derived from the experiences of Northern (or Western) countries. But, knowledge derived from crossregional, intra-regional and inter-regional comparative analysis will make it difficult to deny the significance of the Global South for theorybuilding within the social sciences writ large.

Received / Поступила в редакцию: 14.04.2020 Accepted / Принята к публикации: 13.05.2020 


\section{References / Библиографический список}

Abbott, A. (1988). Transcending General Linear Reality. Sociological Theory, 6 (02), 169-186. DOI: $10.2307 / 202114$

Acharya, A. (2007). The Emerging Regional Architecture of World Politics. World Politics, 59 (04), 629_652. DOI: $10.1353 / \mathrm{wp} .2008 .0000$

Ahmed, A. \& Sil, R. (2012). When Multi-Method Research Subverts Methodological Pluralism — or, Why We Still Need Single-Method Research. Perspectives on Politics, 10 (04), 935-953. DOI: 10.1017/ S1537592712002836

Ahram, A.I. (2011). The Theory and Method of Comparative Area Studies. Qualitative Research, 11 (01), 69—90. DOI: $10.1177 / 1468794110385297$

Ahram, A.I., Köllner, P. \& Sil, R. (Eds.). (2018). Comparative Area Studies: Methodological Rationales and CrossRegional Applications. New York: Oxford University Press. DOI:10.1093/oso/9780190846374.001.0001

Basedau, M. \& Köllner, P. (2007). Area Studies, Comparative Area Studies, and the Study of Politics: Context, Substance, and Methodological Challenges. Zeitschrift für Vergleichende Politikwissenschaft, 1 (01), 105124. DOI: $10.1007 / \mathrm{s} 12286-007-0009-3$

Bates, R.H. (1997). Controversy in the Discipline: Area Studies and Comparative Politics. PS: Political Science and Politics, 30 (02), 166-169. DOI: 10.2307/420485

Berg-Schlosser, D. (2012). Mixed Methods in Comparative Politics: Principles and Applications. London: Palgrave Macmillan. DOI: $10.1057 / 9781137283375$

Brownlee, J. (2007). Authoritarianism in an Age of Democratization. Cambridge: Cambridge University Press. DOI: $10.1017 / \mathrm{CBO} 9780511802348$

Chen, C.P. (2015). Made in Italy (by the Chinese): Migration and the Rebirth of Textiles and Apparel. Journal of Modern Italian Studies, 20 (01), 111-126. DOI: 10.1080/1354571X.2014.973160

Chen, C.P. (2018). Organizing Production across Regions: The Wenzhou Model in China and Italy. In: Ahram, A.I., Köllner, P. \& Sil, R. (Eds.). Comparative Area Studies: Methodological Rationales and Cross-Regional Applications. New York: Oxford University Press. DOI:10.1093/oso/9780190846374.001.0001

Chernilo, D. (2011). The Critique of Methodological Nationalism: Theory and History. Thesis Eleven, 106 (01), 98-117. DOI: $10.1177 / 0725513611415789$

Dunning, T. (2012). Natural Experiments in the Social Sciences: A Design-Based Approach. Cambridge: Cambridge University Press. DOI: 10.1017/CBO9781139084444

El Kurd, D. (2019). Polarized and Demobilized: Legacies of Authoritarianism in Palestine. London: Hurst.

Fioretos, O., Falleti, T.G. \& Sheingate, A. (Eds.) (2016). The Oxford Handbook of Historical Institutionalism. Oxford University Press. DOI: 10.1093/oxfordhb/9780199662814.001.0001

Frazier, M.W. (2019). The Power of Place: Contentious Politics in Twentieth-century Shanghai and Bombay. Cambridge: Cambridge University Press. DOI: 10.1017/9781108698450

Goodin, R.E. \& Tilly, C. (Eds.). (2006). The Oxford Handbook of Contextual Political Analysis. Oxford University Press. DOI: 10.1093/oxfordhb/9780199270439.001.0001

Harbers, I. \& Ingram, M.C. (2017). Geo-Nested Analysis: Mixed-Methods Research with Spatially Dependent Data. Political Analysis, 25 (03), 289-307. DOI: 10.1017/pan.2017.4

Heller, P. (2012). Democracy, Participatory Politics and Development: Some Comparative Lessons from Brazil, India and South Africa. Polity, 44 (04), 643-665. DOI: 10.1057/pol.2012.19

Huber, E. (2003). Letter from the President: The Role of Cross-Regional Comparison. APSA-CP Newsletter, 14 (02), $1-6$.

Katzenstein, P.J. (2015). A World of Regions: Asia and Europe in the American Imperium. Ithaca: Cornell University Press.

King, G. (1996). Why Context Should not Count. Political Geography, 15 (02), 159-164. DOI: 10.1016/09626298(95)00079-8

Köllner, P., Sil, R. \& Ahram, A.I. (2018). Comparative Area Studies: What It Is, What It Can Do. In: Ahram, A.I., Köllner, P. \& Sil, R. (Eds.). Comparative Area Studies: Methodological Rationales and Cross-Regional Applications. New York: Oxford University Press. DOI: 10.1093/oso/9780190846374.001.0001

Lewis, M.W. \& Wigen, K. (1997). The Myth of Continents: A Critique of Metageography. Berkeley: University of California Press.

Lieberman, E. (2009). Boundaries of Contagion: How Ethnic Politics Have Shaped Government Responses to AIDS. Princeton: Princeton University Press.

Mahoney, J. \& Thelen, K. (Eds.) (2015). Advances in Comparative-Historical Analysis. Cambridge: Cambridge University Press. DOI: 10.1017/CBO9781316273104 
Mainwaring, S. \& Pérez-Liñán, A. (2007). Why Regions of The World Are Important: Regional Specificities and Region-Wide Diffusion of Democracy. In: Munck, G.L. (Eds.). Regimes and Democracy in Latin America. Theories and Methods. Oxford Studies in Democratization. New York: Oxford University Press. P. 199-229.

McDermott, R. (2011). Internal and External Validity. In: Lupia, A., Green, D.P., Kuklinski, J.H. \& Druckman, J.N. (Eds.). Cambridge Handbook of Experimental Political Science. Cambridge: Cambridge University Press. P. 27 -40. DOI: 10.1017/CBO9780511921452

Mylonas, H. \& Shelef, N. (2017). Methodological Challenges in the Study of Stateless Nationalist Territorial Claims. Territory, Politics, Governance, 5 (02), 145-157. DOI: 10.1080/21622671.2017.1284020

Pepinsky, T.B. (2017). Regions of Exception. Perspectives on Politics, 15 (04), 1034-1052. DOI: $10.1017 / \mathrm{S} 1537592717002146$

Peters, B.G. (2019). Institutional Theory in Political Science: the New Institutionalism. Cheltenham: Edward Elgar Publishing.

Rihoux, B. \& Ragin, C.C. (Eds.) (2008). Configurational Comparative Methods: Qualitative Comparative Analysis (QCA) and Related Techniques. London: Sage Publications.

Saylor, R. (2014). State Building in Boom Times: Commodities and Coalitions in Latin America and Africa. Oxford: Oxford University Press.

Schaffer, F.C. (2018). Two Ways to Compare. Qualitative and Multi-Method Research, 16 (01), 15-19. DOI: $10.5281 /$ zenodo. 2562165

Sidaway, J.D. (2013). Geography, Globalization, and the Problematic of Area Studies. Annals of the Association of American Geographers, 103 (04), 984-1002. DOI: 10.1080/00045608.2012.660397

Sil, R. (2002). Managing "Modernity”: Work, Community, and Authority in Late-Industrializing Japan and Russia. Ann Arbor: University of Michigan Press. DOI: 10.3998/mpub.17256

Skocpol, T. \& Somers, M. (1980). The Uses of Comparative History in Macrosocial Inquiry. Comparative Studies in Society and History, 22 (02), 174-197. DOI: 10.1017/S0010417500009282

Smith, B. (2018). Comparing Separatism across Regions: Rebellious Legacies in Africa, Asia, and the Middle East. In: Ahram, A.I., Köllner, P. \& Sil, R. (Eds.). Comparative Area Studies: Methodological Rationales and Cross-Regional Applications. New York: Oxford University Press. DOI: 10.1093/oso/ 9780190846374.001.0001

Smith, B.B. (2007). Hard Times in the Lands of Plenty: Oil Politics in Iran and Indonesia. Ithaca: Cornell University Press. DOI: 10.7591/9780801461866

Snyder, R. (2001). Scaling Down: The Subnational Comparative Method. Studies in Comparative International Development, 36 (01), 93-110. DOI: 10.1007/BF02687586

Soest, C.v. \& Stroh, A. (2018). Comparisons across World Regions: Managing Conceptual, Methodological, and Practical Challenges. In: Ahram, A.I., Köllner, P. \& Sil, R. (Eds.). Comparative Area Studies: Methodological Rationales and Cross-Regional Applications. New York: Oxford University Press. DOI: 10.1093/oso/ 9780190846374.001.0001

Solingen, E. (2009). Nuclear Logics: Contrasting Paths in East Asia and the Middle East. Princeton: Princeton University Press.

Thies, C.G. (2002). A Pragmatic Guide to Qualitative Historical Analysis in the Study of International Relations. International Studies Perspectives, 3 (04), 351-372. DOI: 10.1111/1528-3577.t01-1-00099

Tilly, C. (1984). Big Structures, Large Processes, Huge Comparisons. New York: Russell Sage Foundation.

Wedeen, L. (2010). Reflections on Ethnographic Work in Political Science. Annual Review of Political Science, 13, 255-272. DOI: 10.1146/annurev.polisci.11.052706.123951

Wood, E.J. (2000). Forging Democracy from Below: Insurgent Transitions in South Africa and El Salvador. Cambridge: Cambridge University Press.

Wood, E.J. (2003). Insurgent Collective Action and Civil War in El Salvador. Cambridge: Cambridge University Press. DOI: 10.1017/CBO9780511808685

\footnotetext{
About the authors: Sil Rudra - Professor of Political Science, the SAS Director of the Huntsman Program in International Studies \& Business, University of Pennsylvania, USA (e-mail: rudysil@sas.upenn.edu).

Ahram Ariel I. - Associate Professor, School of Public and International Affairs, Virginia Tech, USA (e-mail: ahram@vt.edu).
}

Сведения об авторах: Сил Рудра - профессор политологии и директор (SAS) Программы Хантсмана по международным исследованиям и бизнесу, Университет Пенсильвании, США (е-mail: rudysil@sas.upenn.edu).

Ахрам Ариэль И. - доцент, школа публичных и международных отношений, Политехнический университет Виргинии и университет штата, США (e-mail: ahram@vt.edu). 